\title{
Tectonics and Mineralisation of Copper in the Ardestan-Kahang Area, Central Iran by Remote Sensing
}

\author{
Nazanin Jamalian Daryani ${ }^{1}$, Mehran Arian ${ }^{1}$, Nematllah Rashidnezhad Omran ${ }^{2}$ \\ ${ }^{1}$ Department of Geology, Science and Research Branch, Islamic Azad University, Tehran, Iran \\ ${ }^{2}$ Department of Geology, Tarbiat Modarres University, Tehran, Iran \\ Email: $\underline{\text { mehranarian@yahoo.com }}$
}

Received 20 March 2015; accepted 13 April 2015; published 20 April 2015

Copyright (c) 2015 by authors and Scientific Research Publishing Inc.

This work is licensed under the Creative Commons Attribution International License (CC BY). http://creativecommons.org/licenses/by/4.0/

(c) (i) Open Access

\section{Abstract}

The Ardestan-Kahang area is located in Urmieh-Dokhtar Magmatic Arc. This area is situated in Ardestan, Kouhpayeh, Kajan and Zefreh in 1:100,000 geological maps. In order to extract mineralization zones related to copper mineralization and accessories elements, and also identify Argillic, Prophylitic, Sericitic and Siliceous alteration with major and minor lineaments, various kinds of algorithms, band ratio and personal interpolation have been utilized. The applied methods for extracting alteration consist of LS-Fit (Least Square Fit), Matched Filtering (MF), Spectral Angle Mapper (SAM) and Spectral Feature Fitting (SFF), band ratio and visual interpretation. Comparing different outputs of utilized algorithms illustrates that the best algorithm for argillc alteration extraction are Matched Filtering (MF) and Spectral Feature Fitting (SFF), with visual interpretation, and for argillic alterations the visual interpretation with RGB: 468 that has seen pink-red color. For prophylitic alterations the utilized algorithms are Matched Filtering (MF). Lineaments have extracted with visual interpretation on satellite images and it is revealed that in areas where the fracture density is greater, conditions are more suitable for copper mineralization.

\section{Keywords}

Lineament, Alteration, Copper, Ardestan-Kahang, Central Iran

\section{Introduction}

The remote sensing data are very useful in the mineral exploration, especially in the hydrothermal despites. Iran

*Corresponding author.

How to cite this paper: Daryani, N.J., Arian, M. and Omran, N.R. (2015) Tectonics and Mineralisation of Copper in the Ardestan-Kahang Area, Central Iran by Remote Sensing. Open Journal of Geology, 5, 188-196. 
is located in the Arabian-Eurasian convergent zone with an interesting mineralization setting. It has high potentials for copper deposits. Satellite images have been used by researchers as the first method for interpretation of the alterations and the aim of this research is determination of hydrothermal alteration zones and mineralization of Ardestan-Kahang area based on remote sensing techniques.

\section{Materials and Methods}

\subsection{Geologic Setting}

The Ardestan-Kahang area (Figure 1 ) is located between longitudes $52^{\circ} 25^{\prime} 29^{\prime \prime E}-52^{\circ} 29^{\prime} 42^{\prime \prime E}$ and latitudes $32^{\circ}$ $54^{\prime} 44^{\prime \prime N}-32^{\circ} 57^{\prime} 20 "$ in the Isfahan Province, Central Iran.

This area belongs to Urmieh-Dokhtar Province [1] [2]. Dominant structural trend in Urmieh-Dokhtar Province (Figure 2) is NW-SE. From tectonics view, it contains a magmatic arc that results of subduction to beneath of southern active continental margin of Cimmerian plate. The Width of Urmieh-Dokhtar Province has been increased from Naien city that many parts have covered by quaternary deposits of Dagh Sorkh Kavir, Southern Urmieh Lake, Namak and Hoze Soltan Lakes have formed on it. So, there are a few backland basins with Playa type sedimentation because of dip decreasing in Ben off zone (in NW part of magmatic arc). SE part of magmatic arc has formed on southwest margin of east-central Iran microcontinent [3].

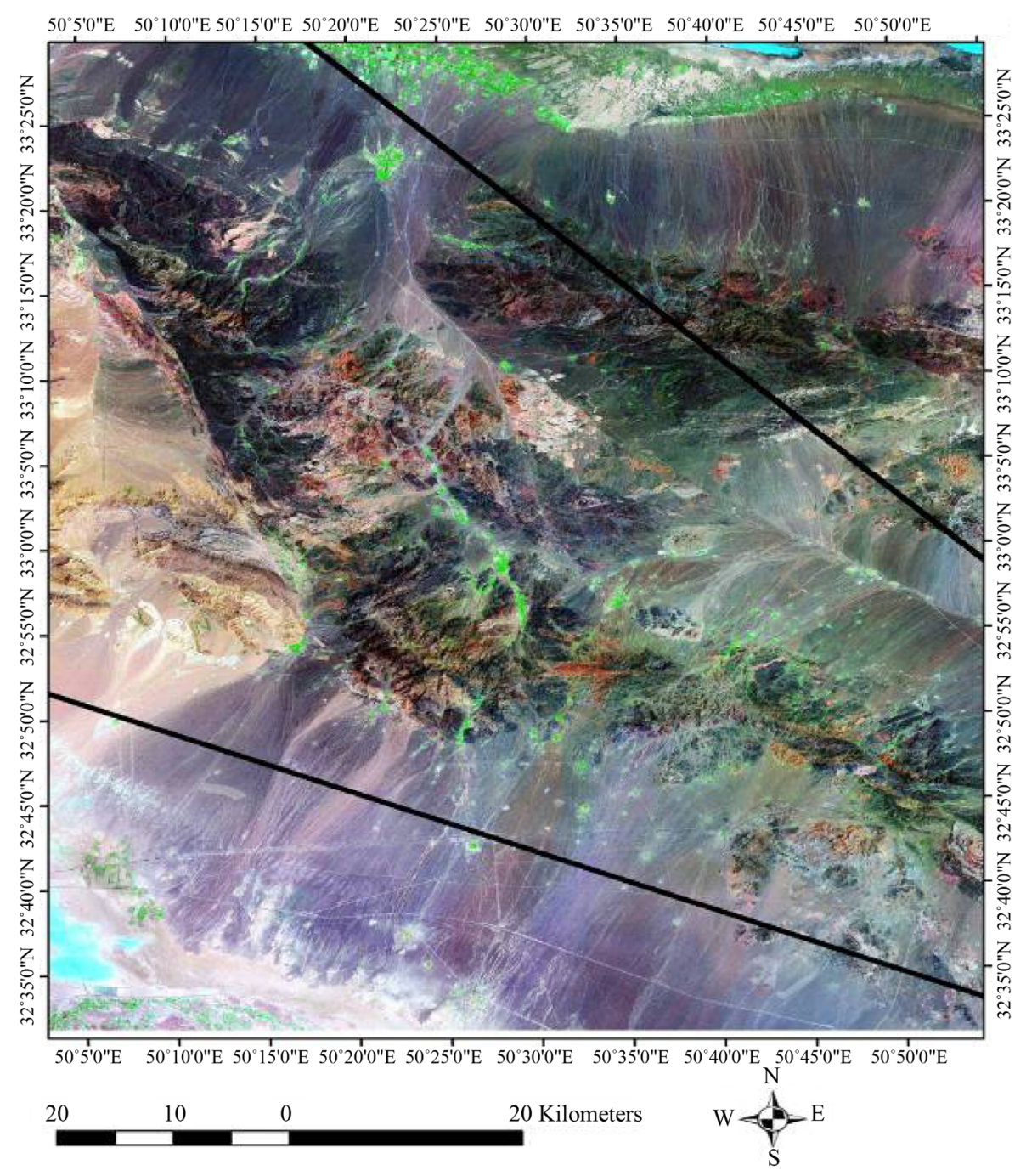

Figure 1. Studied area based on 1:100,000 geological map of Tarom. This area has shown in Figure 2 by a black rectangle. 


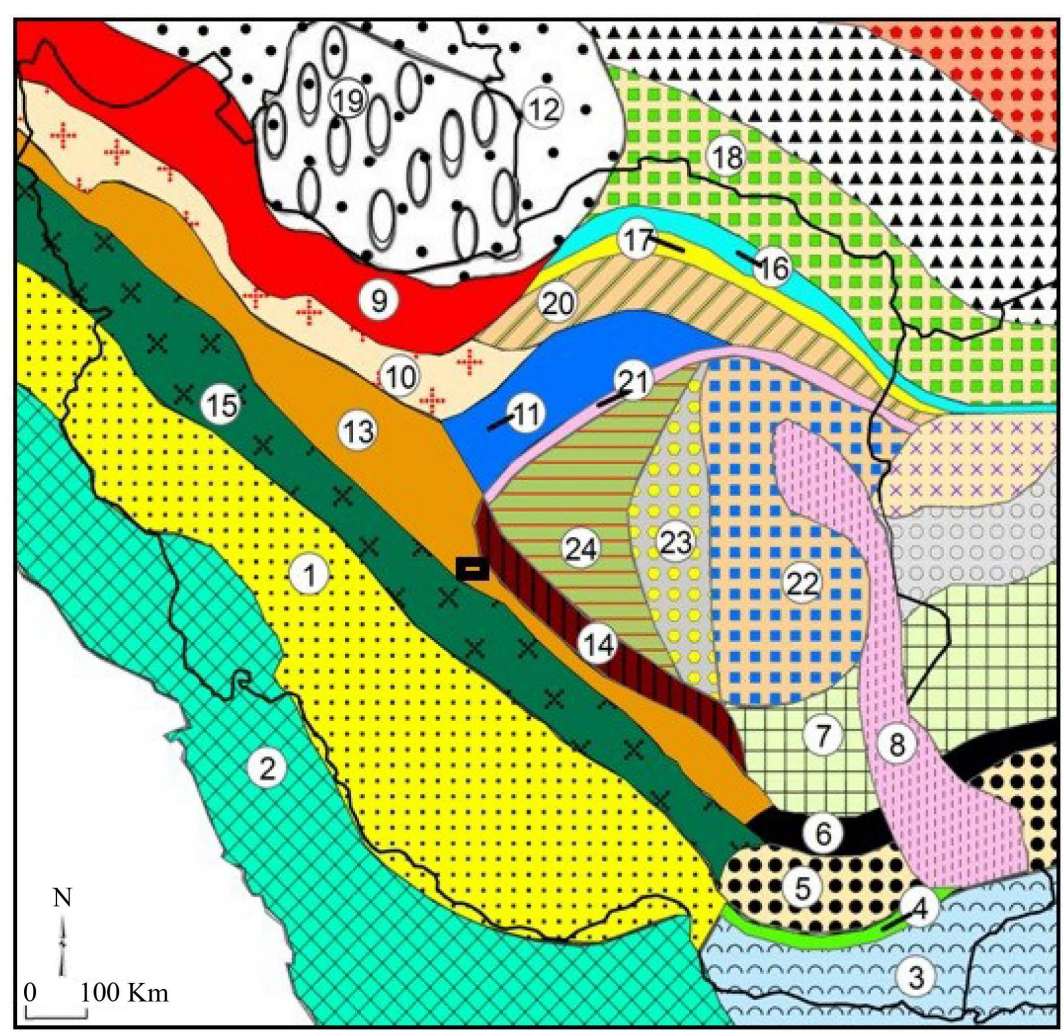

Figure 2. Physiographic-tectonic zoning map of Iran's sedimentary basins modified from [1]. Numbers in this figure are 1: Zagros-East Taurus hinterland; 2: Persian Gulf-Mesopotamian foreland basin; 3: Makran accretionary prism; 4: Bashagard Mountains; 5: Jazmorian-Mashkel fore arc basin; 6: Shahsavaran-Soltan magmatic arc; 7: South Lut-South Helmand back arc basin; 8: East Iran Mountain belt; 9: West-Central Alborz and lesser Caucasus hinterland; 10: Great Kavir-NorthenUrmieh lake foreland basin; 11: South Great Kavirfold and thrust belt, 12: South Caspian-Black sea foreland basin; 13: Urmieh-Dokhtar Magmatic arc; 14: Naien-Kerman retro arc foreland basin; 15: Sanandaj-Sirjanoverthrust belts; 16: East Alborz or Binalod hinterland; 17: Torbat-e am-Neyshabour retro arc foreland basin; 18: KopetDagh hinterland; 19: South Caspian remnant basin; 20: MaiamayTaibad Inverted back arc basin; 21: Khaf-Kavir Plain Magmatic arc; 22: Lut PlainGonabad back arc basin; 23: Tabas hinterland; 24: Yazd-Khour Piggy back basin. The study area is shown in the black rectangle.

This area has an active regime in compared to the north Iran [4]-[19], the central Iran [20]-[28], the south Iran [29]-[35] and salt diapiric areas in Iran [36] [37]. Also, some concepts of copper mineralization in Iran have investigated by [38]-[42]. In this area, volcanic rocks are commonly Eocene andesite, Oligocene-Miocene diorite to granodiorite (as stocks) and late Miocene quartz diorite dykes. Also, in this zone, argillic, propylitic, sericitic and siliceous alterations with major and minor lineaments can be observed in the field.

Based on [43], Porphyry Cu systems are initiated by injection of oxidized magma saturated with S- and metalrich, aqueous fluids from cupolas on the tops of the subjacent parental plutons. The sequence of alteration-mineralization events is principally a consequence of progressive rock and fluid cooling, from $>700^{\circ} \mathrm{C}$ to $<250^{\circ} \mathrm{C}$, caused by solidification of the underlying parental plutons and downward propagation of the lithostatic-hydrostatic transition. Once the plutonic magmas stagnate, the high-temperature, generally two-phase hyper-saline liquid and vapor responsible for the potassic alteration and contained mineralization at depth and early overlying advanced argillic alteration, respectively, gives way, at $<350^{\circ} \mathrm{C}$, to a single-phase, low- to moderate-salinity liquid that causes the sericite-chlorite and sericitic alteration and associated mineralization. This same liquid also causes mineralization of the peripheral parts of systems, including the overlying lithocaps. The progressive thermal decline of the systems combined with synmineral paleosurface degradation results in the characteristic 
overprinting (telescoping) and partial to total reconstitution of older by younger alteration-mineralization types. Meteoric water is not required for formation of this alteration-mineralization sequence although its late ingress is commonplace.

\subsection{ASTER Data}

The ASTER is an advanced optical sensor comprised of 14 spectral channels ranging from the visible to thermal infrared region. It will provide scientific and also practical data regarding various field related to the study of the earth [44]. Various factors affect the signal measured at the sensor, such as drift of the sensor radiometric calibration, atmospheric and topographical effects. For accurate analysis, all of these corrections are necessary for remote sensing imagery.

To this end, at the beginning of the path, our data set in hierarchical data format (HDF) is used for this research and radiance correlation such as wavelength, dark subtract and log residual by ENVI4.4 software which is essential for multispectral images, are implemented.

\section{Results and Discussion}

\subsection{Hydrothermal Alteration Detection}

By using of Spectral Angle Mapper methods, alteration zones were determined [45]. Therefore, image spectra were compared with USGS Digital Spectral Library (Minerals) (Figure 3).

LS-Fit method performs a linear band prediction using least-squares fitting. We could use it to find regions of anomalous spectral response in a dataset. It calculates the covariance of the input data and uses it to predict the selected band as a linear combination of the predictor bands plus an offset. This method has not revealed considerable argillic alterations in the Ardestan-Kahang area.

Use Matched Filtering (MF) to find the abundances of user-defined end members by using a partial immixing. This technique maximizes the response of the known end member and suppresses the response of the composite unknown background, thus matching the known signature. It provides a rapid means of detecting specific materials based on matches to library or image end member spectra and does not require knowledge of all the end members within an image scene. This method may find some false positives for rare materials. The results of this method were suitable for the argillic (Figure 4) and prophylitic alterations (Figure 5).

SAM method is a classification technique that permits rapid mapping by calculating the spectral similarity between the image spectrums to reference reflectance spectra. SAM measures the spectral similarity by calculating the angle between the two spectra, treating them as vectors in n-dimensional space, but it was not suitable for studied area. Use Spectral Feature Fitting (SFF) to compare the fit of image spectra to reference spectra using a least-squares technique. SFF is an absorption-feature-based methodology. The reference spectra are scaled to match the image spectra after the continuum is removed from both datasets. This method has revealed some argillic alterations in the Ardestan-Kahang area.

\subsection{Lineament Extraction}

Lineament extraction in this study is performed in Manual method. In manual extraction method, the lineaments are extracted from satellite image by using visual interpretation. The lineaments usually appear as straight lines

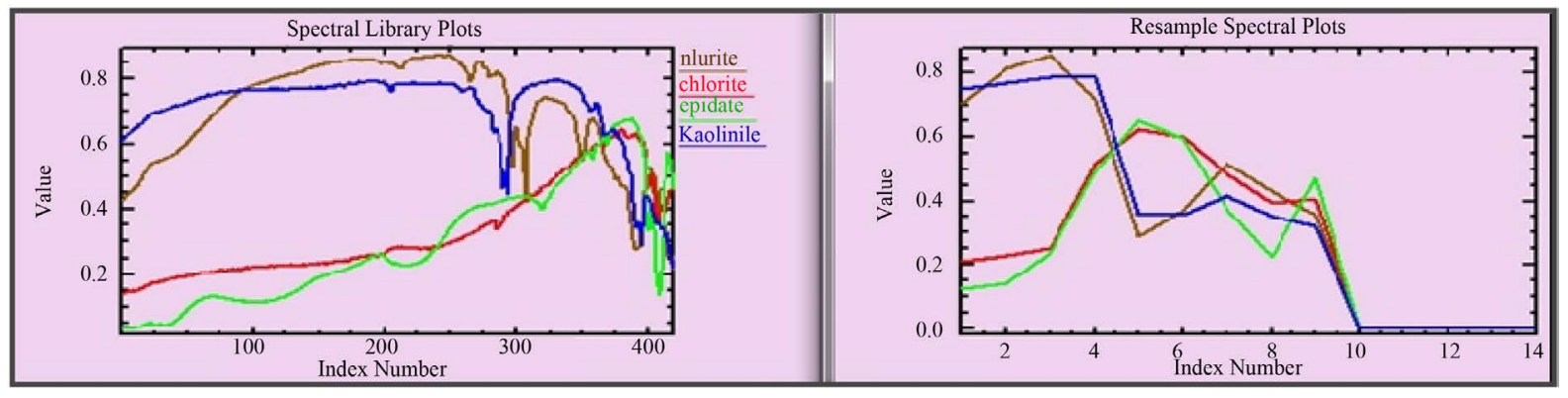

Figure 3. Spectral library plots from ENVI and its resample to ASTER bands. 


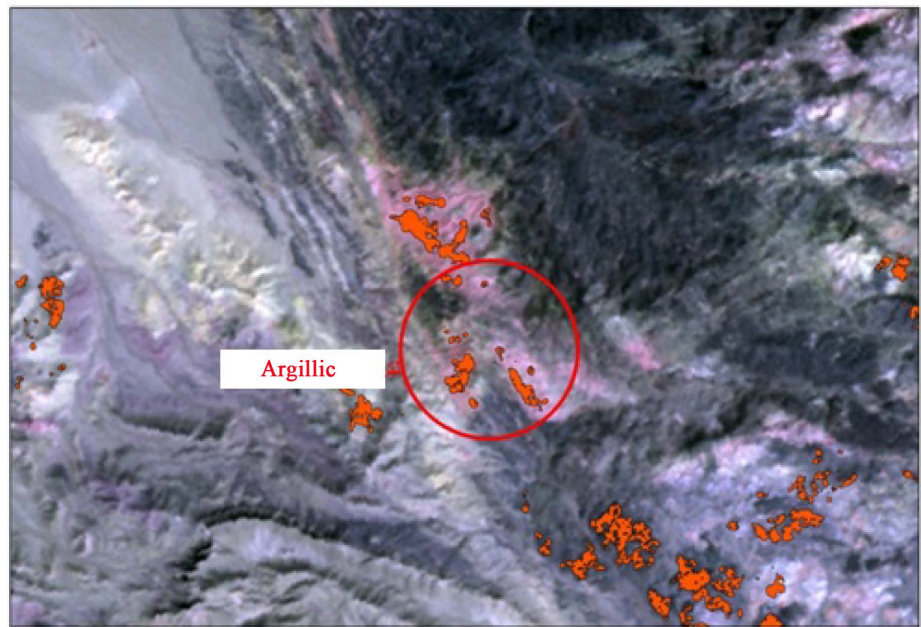

Figure 4. The argillic alteration (red color) by Matched Filtering (MF) method.

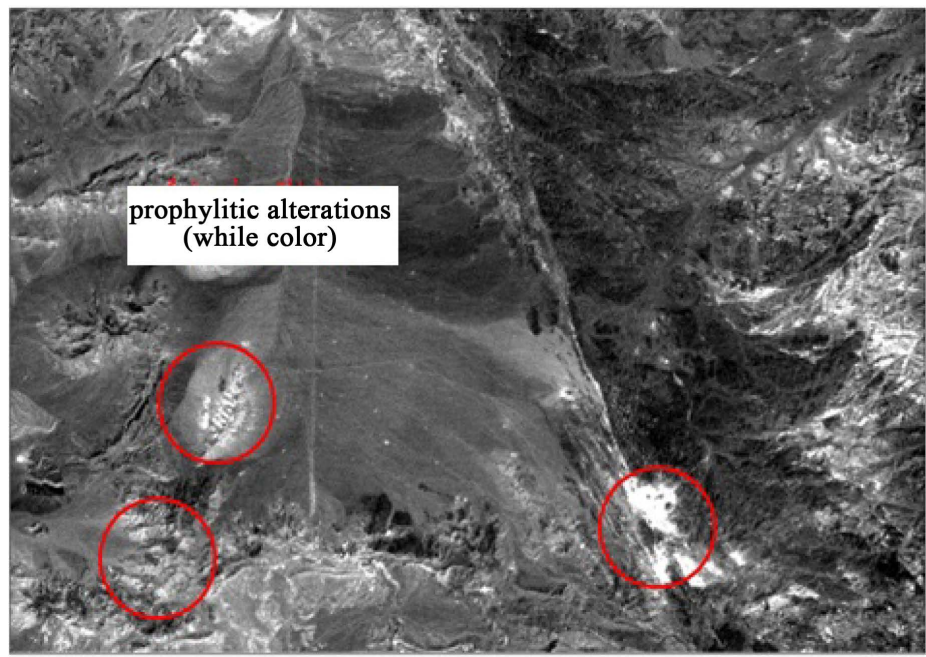

Figure 5. The prophylitic alterations (White color) by Matched Filtering (MF) method.

or edges on the satellite images which in all cases contributed by the tonal differences within the surface material. The researcher experiences have a critical role in determination of the master lineaments.

False color images are produced for manual lineament extraction because they increase the interpretability of the data. Different combinations of three bands are examined and the best visual quality is obtained with a false color image utilizing 7-4-2 and 7-4-1 (Figure 6).

Finally alteration maps of studied area have prepared by using of LS-Fit, Matched Filtering (MF), SAM (Spectral Angle Mapper), SFF(Spectral Feature Fitting), ratio band and visual interpretation (Figure 7).

Also, to evaluate the ASTER satellite data, discriminate alteration zones and lineaments, field-checks have been verified. Almost, in all cases, our fieldworks have confirmed alteration zones and lineaments by the interpreted remote sensing imagery.

\section{Conclusion}

The Ardestan-Kahang area is a copper rich region and it has been revealed by remote sensing and recognition of the hydrothermal alterations. Moreover, ASTER multi spectral images could be used for the identification of lineaments possibly related to faults. The performance of conventional image processing techniques has been 


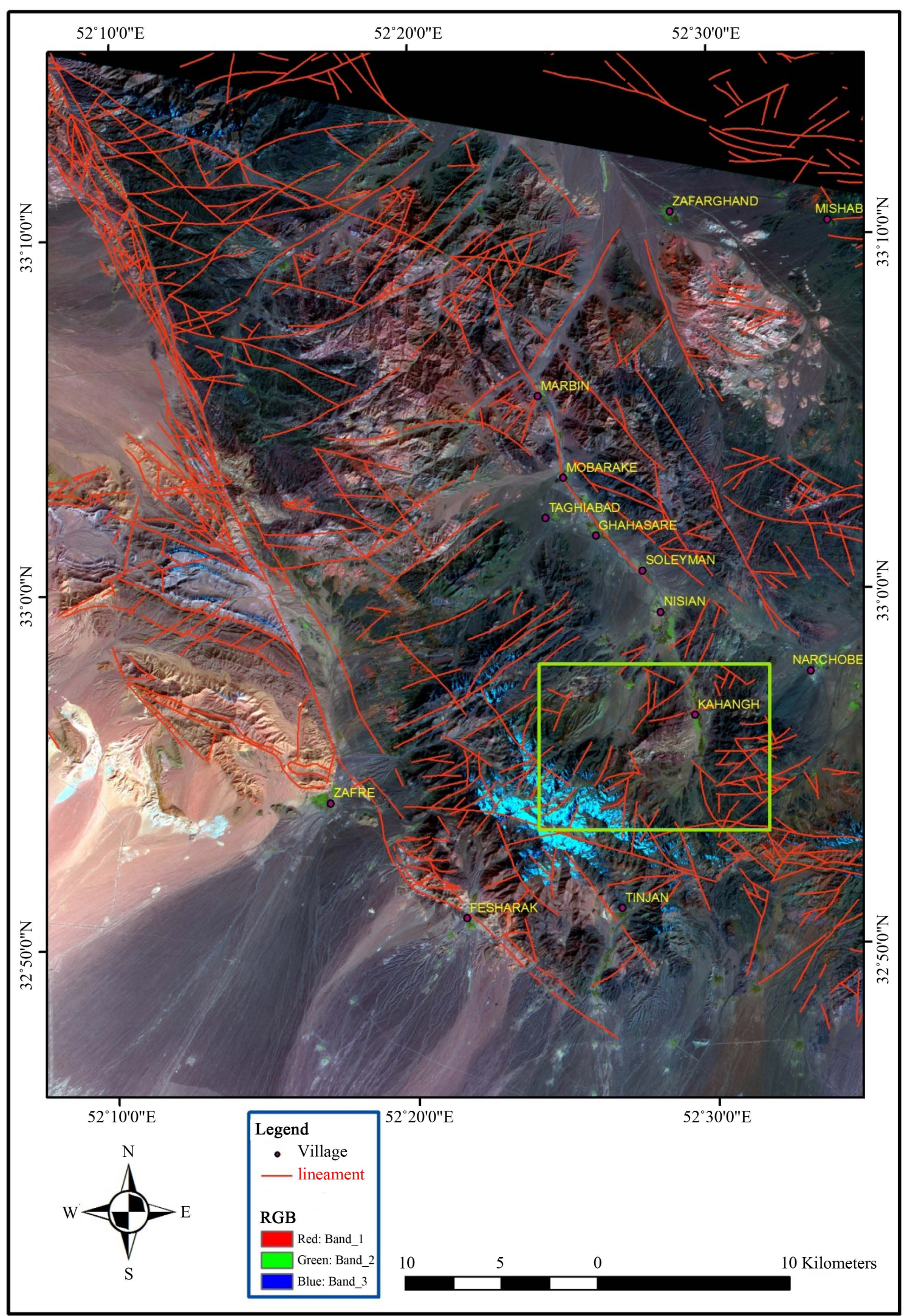

Figure 6. Lineaments of studied area. 


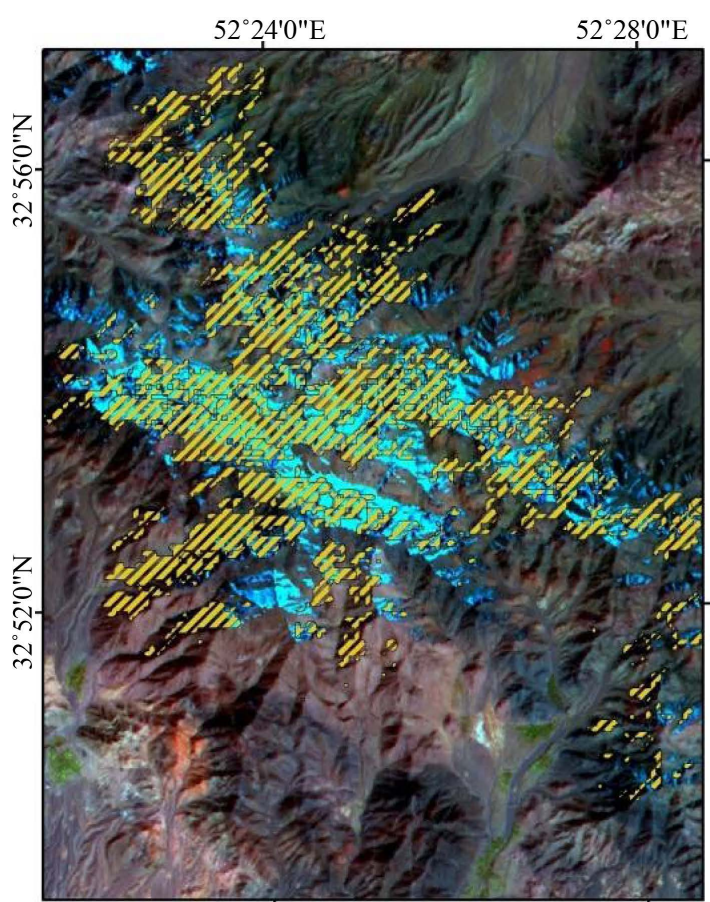

$52^{\circ} 24^{\prime} 0^{\prime \prime} \mathrm{E}$

Siliceous alteration

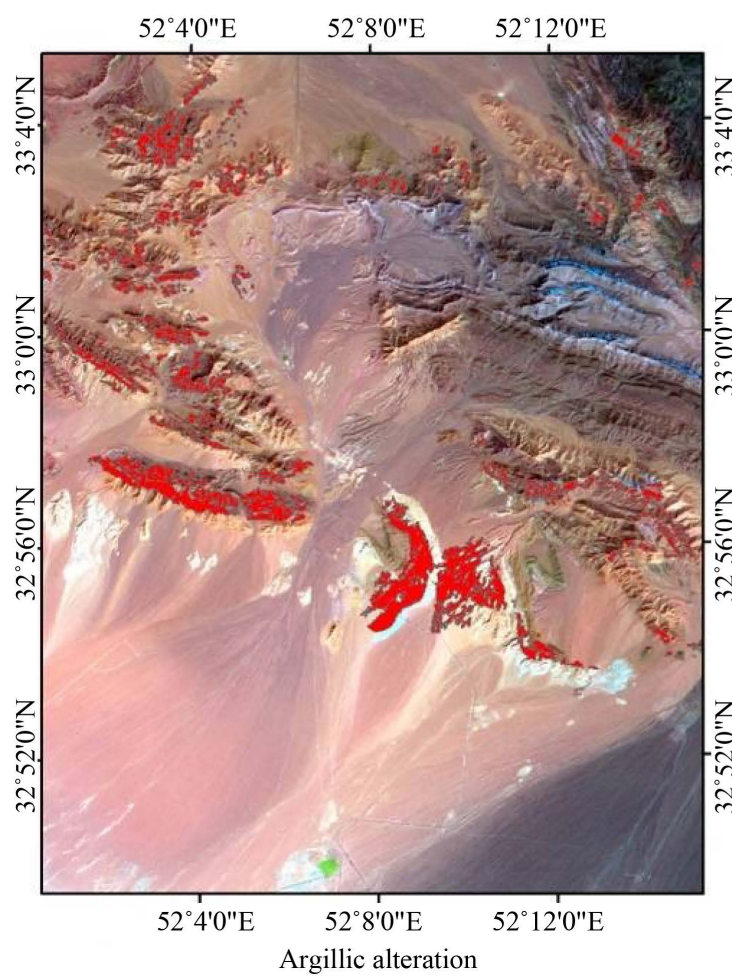

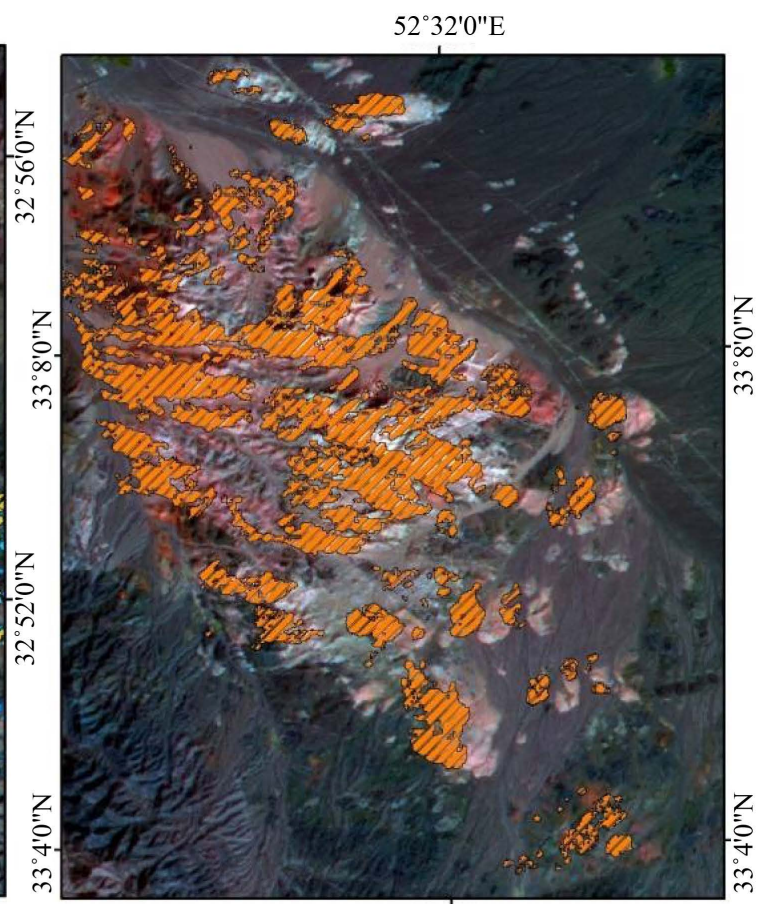

$52^{\circ} 32^{\prime} 0 " \mathrm{E}$

Siliceous alteration

$52^{\circ} 32^{\prime} 0^{\prime \prime} \mathrm{E}$ $52^{\circ} 36^{\prime} 0^{\prime \prime} \mathrm{E}$

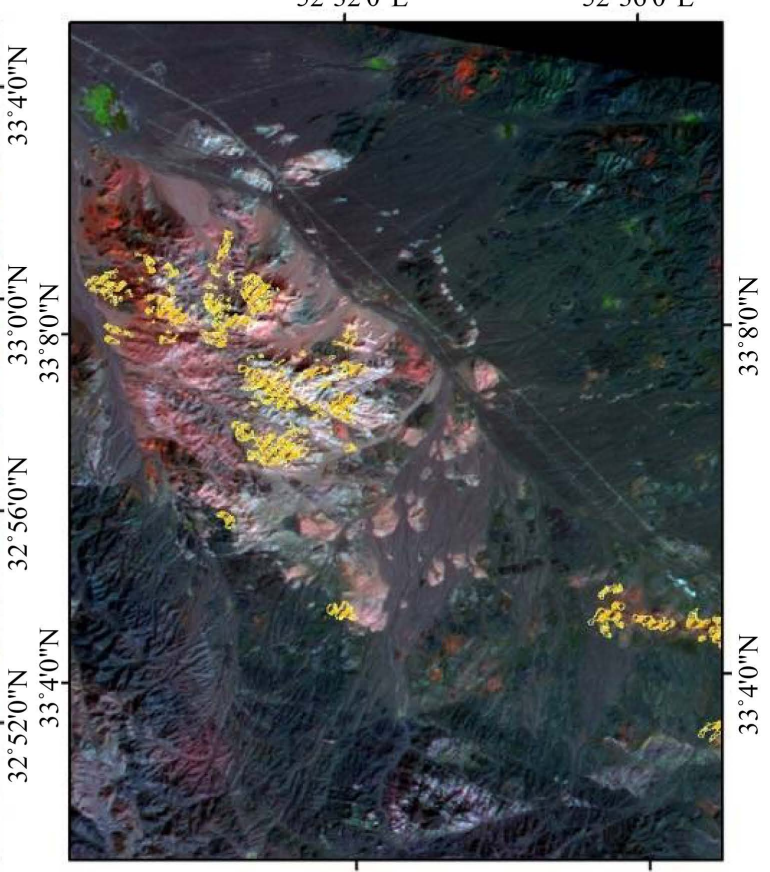

$52^{\circ} 32^{\prime} 0^{\prime \prime} \mathrm{E}$

Prophylitic alteration

Figure 7. Alteration maps of studied area.

evaluated on ASTER bands. Results show that the integration of the image processing techniques has great ability to detect copper oxides and related alterations. Also, there are relationships between alteration zone and tectonic factors, especially faults. It means that, in areas where the fracture density is greater, conditions have been more suitable for mineralization of copper deposits. 


\section{Acknowledgements}

This work has funded by the Department of Geology, Islamic Azad University, Science and Research Branch, Tehran, Iran. Also, special thanks to vice-president for research in Science and Research Branch, Tehran.

\section{References}

[1] Qorashi, M. and Arian, M. (2011) Tectonics of Iran. Geologic Survey of Iran, Tehran, 336 p.

[2] Arian, M. (2011) Basement Tectonics and Geology of Iran. Asar Nafis Press, Qum, 300 p.

[3] Arian, M. (2013) Physiographic-Tectonic Zoning of Iran’s Sedimentary Basins. Open Journal of Geology, 3, $169-177$. http://dx.doi.org/10.4236/ojg.2013.33020

[4] Arian, M., Maleki, Z. and Noroozpour, H. (2011) Cenozoic Diastrophism and Deformational Events in the East-Central Alborz. Journal of Basic and Applied Scientific Research, 1, 2394-2400.

[5] Feizi, F., Arian, A. and Rahmani, R. (2007) Seismotectonic Zoning in the Eastern Part of the Central Alborz. Journal of Sciences, 17, 151-164.

[6] Khavari, R., Arian, M. and Ghorashi. M. (2009) Neotectonics of the South Central Alborz Drainage Basin, in NW Tehran, Iran. Journal of Applied Sciences, 9, 4115-4126. http://dx.doi.org/10.3923/jas.2009.4115.4126

[7] Arian, M. and Bagha N. (2012) Active Tectonics of Tehran Area, Iran. Journal of Basic and Applied Scientific Research, 2, 3805-3819

[8] Bagha, N. Arian, M. Ghorashi, M. Pourkermani, M. El Hamdouni, R. and Solgi, A. (2014) Evaluation of Relative Tectonic Activity in the Tehran basin, Central Alborz, Northern Iran. Geomorphology, 213, 66-87. http://dx.doi.org/10.1016/j.geomorph.2013.12.041

[9] Arian, M. and Feizi, F. (2005) Application of Geomorphic Indices to the Assessment of Relative Tectonic Activity Levels in the Alborz-Central Iran Border Zone (from the East of Varamin to the East of Semnan). Journal of Sciences, 15, 378-403.

[10] Arian, M. and Pourkermani, M. (2004) Tectonic Elements of South Flank in the East-Central Alborz Mountain. Journal of Sciences, 4, 359-368.

[11] Arian, M. and Qorashi, M. (2006) The Movement Potential Evaluation of the Major Quaternary Faults in Alborz-Central Iran Border Zone, from the East of Tehran to the East of Semnan. Journal of Geosciences, 15, 184-188.

[12] Poroohan, N., Pour Kermani, M. and Arian, M. (2013) An Assessment of Relationship in F-Parameter and Paleostress Fields in Heterogeneous Lithologies: Roudbar Area (Northwest of Iran). Australian Journal of Basic \& Applied Sciences, 7, 933-942.

[13] Poroohan, N., Kermani, M.P. and Aryan, M. (2009) An Assessment on Correlations of Seismotectonic Parameters Preceding and Following Roudbar-Manjil Earthquake (Gilan, North of Iran). Australian Journal of Basic \& Applied Sciences, 3, 2643-2652.

[14] Pourkermani, M. and Arian, M. (2001) Structural Geomorphology of Northeastern Kurdistan. Journal of Humanities, 7, 37-48.

[15] Mardani, Z., Ghorashi, M. and Arian, M. (2011) Geomorphic Signatures of Active Tectonics in the Talaghan Rud, Shah Rud and Sefidrud Drainage Basins in Central Alborz, Niran. Geosciences, 20, 159-166.

[16] Sorbi, A., Arian, M. and Pourkermani, M. (2011) The Application of Geomorphic Indices to the Assessment of Relative Tectonic Activity Levels in Tehran Quadrangle. Journal of the Earth, 6, 1-9.

[17] Khavari, R., Ghorashi, M., Arian, M. and Khosrotehrani, K. (2010) Geomorphic Signatures of Active Tectonics in the Karaj Drainage Basin in South Central Alborz, Iran. Geosciences, 19, 67-74.

[18] Javadi Mousavi, E. and Arian, M. (2015) Tectonic Geomorphology of Atrak River, NE Iran. Open Journal of Geology, 5, 106-114.

[19] Moghimi, H., Arian, M. and Sorbi, A. (2015) Fault Movement Potential of Marzanabad Area, North Alborz, Iran. Open Journal of Geology, 5, 126-135. http://dx.doi.org/10.4236/ojg.2015.53012

[20] Arian, M., Toudeshki, V.H. and Noroozpour, H. (2011) Active Tectonics of Qezel Ozan River Basin, NW Iran. Journal of Applied Environmental and Biological Sciences, 1, 291-295.

[21] Housini Toudeshki, V., Pourkermani, M., Arian, M. and Khosrotehrani, K.H. (2011) Influence of Structures on the Ghezel Ozan River. Geosciences, 21, 55-60.

[22] Housini Toudeshki, V. and Arian, M. (2011) Morphotectonic Analysis in the Ghezel Ozan River Basin, NW Iran. Journal of Geography and Geology, 3, 258-260. http://dx.doi.org/10.5539/jgg.v3n1p258

[23] Arian, M. (2012) Clustering of Diapiric Provinces in the Central Iran Basin. Carbonates and Evaporites, 27, 9-18. 
http://dx.doi.org/10.1007/s13146-011-0079-9

[24] Pourkermani, M. and Arian, M. (1997) Salt Domes of Central Iran. Journal of Humanities, 3, 29-41.

[25] Arian, M., Pourkermani, M., Sistanipour, A. and Noroozpour, H. (2011) Kinematic Significance of Fold- and FaultRelated Fracture Systems in the Rafsanjan’s Northeast Highlands (Central Iran). Journal of Basic and Applied Scientific Research, 1, 3398-3406.

[26] Arian, M., Pourkermani, M., Sistanipour, A. and Noroozpour, H. (2011) Seismicity and Fault Segmentation of BafqBaghin Fault System (Central Iran). Journal of Applied Environmental and Biological Sciences, 1, 382-396.

[27] Asadian, F. and Arian, M. (2009) Identification of Diapiric Provinces of Central Iran through Geological and Geographical Analysis. International Journal of Agriculture Environment Biotechnology, 2, 3443-3451.

[28] Arian, M. (2010) Earthquake-Fault Hazard Investigations in the Kerman Quadrangle. Journal of Sciences, 19, 176182.

[29] Arian, M. and Aram, Z. (2014) Relative Tectonic Activity Classification in the Kermanshah Area, Western Iran. Solid Earth, 5, 1277-1291. http://dx.doi.org/10.5194/se-5-1277-2014

[30] Mashal, M., Kermani, M.P., Charchi, A., Almasian, M. and Arian, M. (2013) Pattern of Structural Geology Underground in Eastern of North Dezfol Embayment. Advances in Environmental Biology, 7, 260-268.

[31] Pazhoohan, M., Arian, M., Ghorashi, M. and Khosrotehrani, K. (2014) A Study of Drainage Pattern Responses to Active Tectonics in Tadvan Region, SW Iran. Geodynamics, 1, 36-41.

[32] Rahimi, N. and Arian, M. (2014) Tectonic Geomorphplogy of Hamedan-Sosangerd Region, West Iran. Advances in Environmental Biology, 8, 119-124.

[33] Arian, M. and Hashemi, A. (2008) Seismotectonic Zoning in the Zagros. Journal of Sciences, 18, 63-76.

[34] Arian, M., Ahmadnia, A., Qorashi, M. and Pourkermani, M. (2002) Structural Analysis of Mengharak Transcurrent Fault System in Zagros, Iran. Special GEO 2002 Conference Issue Geoarabia, 7, 209-210.

[35] Arian, M., Qorashi, M., Pourkermani, M. and Ahmadnia, A. (2006) The Structural Significance Kareh Bas Transcurrent Fault System in the Zagros Fold and Thrust Belt. Journal of Geosciences, Geological Survey of Iran, 15, 126-133.

[36] Arian, M. and Noroozpour, H. (2015) The Biggest Salt-Tongue Canopy of Central Iran. Open Journal of Geology, 5, 55-60. http://dx.doi.org/10.4236/ojg.2015.52005

[37] Arian, M. and Noroozpour, H. (2015) Tectonic Geomorphology of Iran’s Salt Structures. Open Journal of Geology, 5, 61-72. http://dx.doi.org/10.4236/ojg.2015.52006

[38] Nouri, R., Jafari, M.R., Arian, M., Feizi, F. and Afzal, P. (2013) Correlation between Cu Mineralization and Major Faults Using Multifractal Modeling in the Tarom Area (NW Iran). Geologica Carpathica, 64, 409-416.

[39] Nouri, R., Jafari, M.R., Arian, M., Feizi, F. and Afzal, P. (2013) Prospection for Copper Mineralization with Contribution of Remote Sensing, Geochemical and Mineralographical Data in Abhar 1:100,000 Sheet, NW Iran. Archives of Mining Sciences, 58, 1071-1084.

[40] Nouri, R., Afzal, P., Arian, M., Jafari, M. and Feizi, F. (2013) AHP in the Rudbar 1: 100,000 Map Sheet, Northwest Iran. Journal of Mining and Metallurgy, 49, 9-19.

[41] Feizi, F. and Arian, M. (2011) The Role of Structural Controllers in Geneses of Copper Deposits in 1: 50000 Map of Sain Qaleh. Journal of Sciences, 21, 1-10.

[42] Arian, M. and Nouri, R. (2015) Lineament Tectonics and Mineralization in Tarom Area, North Iran. Open Journal of Geology, 5, 115-125.

[43] Sillitoe, R.H. (2010) Porphyry Copper Systems. Economic Geology, 105, 3-41. http://dx.doi.org/10.2113/gsecongeo.105.1.3

[44] Watanabe, H. and Matsuo, K. (2003) Rock Type Classification by Multi-Band TIR of ASTER. Geosciences Journal, 7, 347-358. http://dx.doi.org/10.1007/BF02919567

[45] Pour, A.B. and Hashim, M. (2012) Identifying Areas of High Economic-Potential Copper Mineralization Using ASTER Data in the Urumieh-Dokhtar Volcanic Belt, Iran. Advances in Space Research, 49, 753-769. http://dx.doi.org/10.1016/j.asr.2011.11.028 